\title{
PENGARUH PEMBERIAN AROMATERAPI LAVENDER TERHADAP PENGENDALIAN NYERI PERSALINAN KALA I PADA IBU BERSALIN
}

\section{Susilarini, Sri Winarsih, Ribkha Itha Idhayanti}

Email:itharibkha@yahoo.com

\begin{abstract}
The purpose of this research was to determine the effect of lavender aromatherapy on pain control first stage of labor on maternal. This research was conducted in Jumo primary health centers Temanggung. This study uses a quasiexperimental design One group pretest-posttest design. The study population was all women giving birth in Jumo primary health centers Temanggung using a sampling technique total sampling obtained a total of 33 maternal. The results showed that there is the effect of lavender aromatherapy on pain control first stage of labor on maternal $p$ value of 0.001 . From the results of the study are expected in particular health care services for women giving birth in order to provide a service that not only focused on physical problems, but also solves the problem of psychology is to optimize the role of health workers, particularly midwives in intervention, not only collaborative action alone.
\end{abstract}

Keyword : Lavender Aromatherapy, Labor Pain, Mother Maternity

1) Student of Diploma Programme Midwifery Magelang

2) 3) Lecture of Diploma Programme Midwifery Magelang 
Nyeri persalinan dapat terjadi pada semua ibu bersalin, baik ibu bersalin primi maupun multi karena menurut Judha (2012) nyeri disebabkan karena adanya peregangan perineum dan vulva, adanya tekanan uterus vertical saat kontraksi dan adanya penekanan bagian terendah janin secara progresif pada fleksus lumboskral, kandung kemih, dan struktur sensitive panggul yang lain.

Nyeri persalinan mengakibatkan rasa takut dan stres. Stres pada ibu akan menyebabkan pengeluaran hormon stres seperti katekolamin dan steroid sehingga mengakibatkan pengurangan aliran darah ibu ke janin. Untuk mengurangi efek stres fisiologis maupun psikologis akibat nyeri persalinan dapat dilakukan melalui penanganan nonfarmakologi dengan cara penghirupan aromaterapi lavender, karena tidak memberikan efek invasif tetapi aman bagi ibu maupun bayi (Tarsikah, 2012), karena menurut penelitian terdahulu oleh Lis-Balchin (2009), kandungan lavender oil yang terdiri dari: linalool, linalyl acetate, $\alpha$ dan $\beta$ - pinene dan 1,8- cineole dapat menurunkan secara spontan kontraksi uterus pada tikus yang sedang mengalami spasme pada otot intestinalnya.

Penanganan nyeri persalinan dapat dilakukan melalui beberapa upaya yang menurut Maryunani (2010) secara farmakologis dapat diberikan analgetik dan anesthesia, sedangkan penanganan nyeri secara non farmakologis dapat diberikan teknik relaksasi, hypnobirthing, akupunktur, akupresur, wather birth, massage, dan aromaterapi. Untuk penanganan nyeri non farmakologis seperti teknik hypnobirthing, akupunktur, akupresur, water birth harus dilakukan oleh tenaga kesehatan yang terlatih karena untuk perasat tersebut memerlukan pelatihan khusus, sedangkan untuk pemberian aromaterapi hanya memerlukan bahan aromaterapi. Berdasarkan survey awal yang penulis lakukan di wilayah Puskesmas Jumo, ibu-ibu lebih menyukai aroma wangi-wangian daripada tindakan pemijatan pada saat mengalami nyeri persalinan dikarenakan ada sebagian ibu yang pada saat nyeri atau kontraksi terjadi tidak mau disentuh apalagi dilakukan pemijatan.

Saat ini proses persalinan pevaginam telah berkembang, bertujuan memberi rasa nyaman, aman dan menyenangkan, serta dapat mengurangi dan bila mungkin meniadakan rasa cemas dan menegangkan. Ada beberapa metode nonfarmakologis yang dapat diterapkan dalam mengurangi nyeri persalinan, salah satunya adalah dengan aromaterapi. Pertama diperkenalkan di Inggris pada awal tahun 1990, aromaterapi menggunakan ekstrak wewangian tertentu untuk menebar aroma dalam ruang bersalin. Efeknya dapat menenangkan, hilangnya rasa cemas dan relaksasi ibu bersalin. Dalam penelitian di Inggris, aroma bunga mawar mempunyai efek yang paling besar, kemudian bunga lavender (Gondo, 2010). Berdasarkan survey awal 7 ibu hamil trimester III di wilayah Puskesmas Jumo, mereka lebih memilih aroma lavender dibanding mawar karena mereka beranggapan aroma mawar seperti bau bunga kuburan dan akan merasa lebih tegang pada saat persalinan berlangsung.

Penggunaan aromaterapi lavender dapat digunakan pada proses persalinan kala I karena menurut Judha (2012) mekanisme secara intrinsik pada nyeri persalinan kala I seluruhnya terjadi pada uterus dan adnexa selama kontraksi berlangsung. Rasa nyeri pada setiap fase 
persalinan dihantarkan oleh segmen saraf yang berbeda-beda. Nyeri pada kala I terutama berasal dari uterus.

Beberapa penelitian telah menunjukkan bahwa lavender efektif dijadikan aromaterapi, seperti pada hasil penelitian Dasna (2013) yang menunjukkan bahwa ada perbedaan antara skala nyeri sebelum dan sesudah pemberian terapi aroma lavender pada klien infark miokard, dan hasil penelitian Swandari (2014) yang menunjukkan ada perbedaan nyeri sebelum dan sesudah pemberian aromaterapi lavender pada ibu post section Caesar di RSUD Ambarawa. Aromaterapi lavender juga menurunkan tingkat kecemasan seperti hasil penelitian Arwani (2013) pada pasien sebelum operasi dengan anestesi spinal di RS Tugu Semarang

Berdasarkan survei awal yang dilakukan pada bulan Desember 2015 di Puskesmas Jumo beberapa bidan mengaku bahwa semua ibu bersalin mengalami nyeri persalinan, dan berdasarkan hasil pengamatan langsung pada 5 ibu bersalin, semua ibu menyatakan bahwa nyeri terasa seperti ditusuk-tusuk, panas menjalar di sepanjang pinggang dan perut bawah, dan berdasarkan pengamatan langsung saat proses persalinan belum pernah ada yang menggunakaan aromaterapi untuk mengatasi rasa nyeri pada saat proses persalinan. Jumlah persalinan tahun 2015 untuk wilayah kerja Puskesmas Jumo adalah 553 ibu bersalin. Angka tersebut cukup tinggi dibanding di wilayah lain, Puskesmas Traji jumlah persalinan tahun 2015 sejumlah 270 ibu bersalin, Puskesmas Darmorini sejumlah 509 ibu bersalin. Dari survey awal terhadap beberapa bidan praktek mandiri di wilayah Puskesmas Jumo, mereka mengatakan bahwa hampir semua ibu bersalin mengalami nyeri persalinan khususnya pada kala I.

Tujuan dari penelitian ini adalah untuk mengetahui pengaruh pemberian aromaterapi lavender terhadap pengendalian nyeri persalinan kala I pada ibu bersalin.

\section{METODE PENELITIAN}

Penelitian ini merupakan bentuk penelitian kuantitatif dengan metode yang digunakan dalam penelitian ini adalah quasi experiment dengan desain One group pre test-post test Design. Tujuan dari penelitian ini adalah untuk menganalisis pengaruh pemberian aromaterapi lavender terhadap pengendalian nyeri persalinan kala I pada ibu bersalin. Populasi penelitian ini adalah semua ibu bersalin di wilayah kerja Puskesmas Jumo Kabupaten Temanggung dengan menggunakan teknik sampling total sampling diperoleh sebanyak 33 ibu bersalin. Teknik pengumpulan data dilakukan adalah dengan menggunakan lembar checklist berisi skala nyeri yaitu lembar penilaian skala nyeri Bourbanis Analisa data dengan menggunakan uji Wilcoxon dengan kepercayaan sebanyak $95 \%$.

\section{HASIL PENELITIAN}

Hasil penelitian menunjukkan bahwa sebagian besar ibu bersalin sebelum mendapatkan perlakuan dengan aromaterapi lavender mengalami nyeri sedang sebanyak 29 responden $(87,9 \%)$. Hal ini menunjukkan bahwa sebagian besar ibu bersalin mengalami nyeri persalinan.

Penyebab terjadinya nyeri persalinan menurut Maryunani (2010) karena adanya rangsangan nyeri yang dihantarkan ke otak melalui jalur saraf tertentu. Hasil penelitian Tarsikah (2012) juga menunjukkan bahwa 
skor nyeri persalinan sebelum perlakuan penghirupan aromaterapi minimal 5 (nyeri sedang) dan maksimal 10 (nyeri hebat).

\section{PEMBAHASAN}

Dipandang dari proses persalinan rasa nyeri sebenarnya tidak diperlukan. Kenyataanya kontraksi rahimlah yang membantu proses pengeluaran bayi. Nyeri juga menimbulkan beberapa perubahan yang sangat signifikan dalam tubuh ibu bersalin, sedangkan menurut Judha (2012) nyeri dapat terjadi pada ibu primi maupun multi yang disebabkan karena adanya peregangan perineum dan vulva, adanya tekanan uterus vertical saat kontraksi dan adanya penekanan bagian terendah janin secara progresif pada fleksus lumboskral, kandung kemih, dan struktur sensitive panggul yang lain.

Nyeri persalinan menurut Maryunani (2010) adalah nyeri kontraksi uterus yang dapat mengakibatkan peningkatan aktifitas system saraf simpatis, perubahan tekanan darah, denyut jantung,pernafasan, dengan warna kulit dan apabila tidak segera diatasi maka akan meningkatkan rasa khawatir, tegang, takut dan stress.

Munculnya nyeri sangat berkaitan erat dengan reseptor dan adanya rangsangan. Reseptor nyari yang dimaksud adalah nociceptor, merupakan ujung-ujung saraf sangat bebas yang memiliki atau bahkan myelin yang tersebar pada kulit dan mukosa, khususnya pada organ viseral, persendian, dinding arteri, hati dan kandung empedu. Reseptor nyeri dapat memberikan respon akibat adanya stimulasi atau rangsangan. Stimulasi tersebut dapat berupa zat kimiawi seperti histamin, brakidini, prostaglandin, dan macam-macam asam yang dilepas apabila terdapat kerusakan pada jaringan akibat kekurangan oksigen. Stimulasi yang lain dapat berupa termal, listrik atau mekanis. (Maryunani, 2010).

Selanjutnya stimulasi yang diterima oleh respon tersebut ditransmisikan berupa implus-implus nyeri ke sumsum tulang belakang oleh dua jenis serabut yang bermyelin rapat atau serabut $A$ (delta) dan serabut lamban (serabut $C$ ). Implus-implus yang ditrasmisikan oleh serabut delta $A$ mempunyai sifat inhibitor yang ditrasmisikan ke serabut $C$. Serabut-serabut eferen masuk ke spinal melalui akar dorsal (dorsal root) sera sinapas pada dorsal horn, dorsal horn sendiri terdiri atas beberapa lapisan atau laminae yang saling bertautan. Diantara lapisan dua dan tiga membentuk substansi gelatinosa yang merupakan saluran utama impuls. Kemudian impuls nyeri menyeberang sumsum tulang belakang pada interneuron dan bersambung ke jalur spinal asendens yang paling utama, yaitu jalur spinothalamic tract (SST) atau jalur spinothalamus dan spinoreticular tract (SRT) yang membewa informasi mengenai sifat dan lokasi nyeri. Dari proses transmisi terdapat dua jalur mekanisme terdapat dua jalur terjadinya nyeri yaitu jalur opiate dan jalur nonopiate, jalur opiate ditandai oleh pertemuan reseptor pada otak yang terdiri atas jalur soinal desendens dari thalamus yang melalui otak tengah dan medulla ke tanduk dorsal tulang belakang yang berkonduksi dengan nociceptorimpuls supresif. Serotonim merupakan neurotransmitter dan inpuls supresif. Sistem supresif lebih mengaktifkan stimulasi nociceptor yang ditransmisikan oleh serabut $A$. Jalur nonopiate merupakan jalur desenden yang tidak memberikan respon terhadap nalox-one yang kurang banyak diketahui mekanismenya. (Maryunani, 2010). 
Hasil penelitian menunjukkan bahwa ibu bersalin setelah mendapatkan perlakuan dengan aromaterapi lavender mengalami penurunan nyeri menjadi nyeri ringan sebanyak 26 responden (78,8\%), tidak nyeri sebanyak 5 responden $(15,2 \%)$ dan nyeri sedang sebanyak 2 reponden $(6,1 \%)$. Hal ini menunjukkan bahwa sebagian besar ibu bersalin mengalami penurunan nyeri persalinan setelah mendapatkan aromaterapi lavender. Nyeri ringan menurut Batbual (2010) dengan ciri-ciri secara obyektif klien dapat berkomunikasi dengan baik.

Aromaterapi menurut Watt, Gillian, \& Janca (2008) adalah penggunaan minyak esensial konsentrasi tinggi yang diekstraksi dari tumbuh-tumbuhan dan diberikan melalui pijat, inhalasi, dicampur ke dalam air mandi, untuk kompres, melalui membran mukosa dalam bentuk pesarium atau supositoria dan terkadang dalam bentuk murni. Aromaterapi adalah terapi yang menggunakan minyak essensial yang dinilai dapat membantu mengurangi bahkan mengatasi gangguan psikologis dan gangguan rasa nyaman seperti cemas, depresi, nyeri, dan sebagainya.

Lavender merupakan salah satu jenis aromaterapi. Aromaterapi lavender menurut Tarsikah (2012) merupakan salah satu minyak esensial analgesik yang mengandung $8 \%$ terpena dan $6 \%$ keton. Monoterpena merupakan jenis senyawa terpena yang paling sering ditemukan dalam minyak atsiri tanaman. Pada aplikasi medis monoterpena digunakan sebagai sedatif. Minyak lavender juga mengandung 30-50\% linalil asetat. Linalil asetat merupakan senyawa ester yang terbentuk melalui penggabungan asam organik dan alkohol. Ester sangat berguna untuk menormalkan keadaan emosi serta keadaan tubuh yang tidak seimbang, dan juga memiliki khasiat sebagai penenang serta tonikum, khususnya pada sistem saraf.

Wangi yang dihasilkan aromaterapi lavender akan menstimulasi talamus untuk mengeluarkan enkefalin, berfungsi sebagai penghilang rasa sakit alami. Enkefalin merupakan neuromodulator yang berfungsi untuk menghambat nyeri fisiologi.

Hasil penelitian menunjukkan uji analisis data dengan uji Wilxocon dengan hasil z hitung sebesar 5,507 dan $p$ value sebesar 0,001 yang artinya $\mathrm{Ha}$ ditolak dan $\mathrm{Ho}$ diterima, sehingga ada pengaruh pemberian aromaterapi lavender terhadap pengendalian nyeri persalinan kala I pada ibu bersalin.

Hasil penelitian ini sejalan dengan hasil penelitian Dasna (2013) yang menunjukkan bahwa ada perbedaan antara skala nyeri sebelum dan sesudah pemberian terapi aroma lavender pada klien infark miokard, dan hasil penelitian Swandari (2014) yang menunjukkan ada perbedaan nyeri sebelum dan sesudah pemberian aromaterapi lavender pada ibu post section Caesar di RSUD Ambarawa. Aromaterapi lavender juga menurunkan tingkat kecemasan seperti hasil penelitian Arwani (2013) pada pasien sebelum operasi dengan anestesi spinal di RS Tugu Semarang.

Penggunaan aromaterapi lavender dapat digunakan pada proses persalinan kala I karena menurut Judha (2012) mekanisme secara intrinsik pada nyeri persalinan kala I seluruhnya terjadi pada uterus dan adnexa selama kontraksi berlangsung. Rasa nyeri pada setiap fase persalinan dihantarkan oleh segmen saraf yang berbeda-beda. Nyeri pada kala I terutama berasal dari uterus. 
Nyeri persalinan mengakibatkan rasa takut dan stres. Stres pada ibu akan menyebabkan pengeluaran hormon stres seperti katekolamin dan steroid sehingga mengakibatkan pengurangan aliran darah ibu ke janin. Nyeri hebat dan kontinu akibat kontraksi rahim dapat menimbulkan perubahan fisiologis tubuh yang bermakna (hiperventilasi 4-20 kali normal) dengan alkalosis berat, kenaikan curah jantung (50$150 \%)$, kenaikan tekanan darah (20-40\%), kenaikan metabolisme dan konsumsi oksigen, sedangkan motilitas saluran pencernaan dan buli-buli menurun. Untuk mengurangi efek stres fisiologis maupun psikologis akibat nyeri persalinan dapat dilakukan melalui penanganan nonfarmakologi dengan cara penghirupan aromaterapi lavender, karena tidak memberikan efek invasif tetapi aman bagi ibu maupun bayi (Tarsikah, 2012), karena menurut penelitian terdahulu oleh LisBalchin (2009), kandungan lavender oil yang terdiri dari: linalool, linalyl acetate, $\alpha$ dan $\beta$ - pinene dan 1,8- cineole dapat menurunkan secara spontan kontraksi uterus pada tikus yang sedang mengalami spasme pada otot intestinalnya, sehingga menurut Ogan (2005) minyak aromatherapi lavender dikenal sebagai minyak penenang, efek sedative lavendula angustifolia terjadi karena adanya senyawa-senyawa coumarin dalam minyak tersebut.

Hal ini ditunjukkan dengan hasil sebelum diberikan aromaterapi lavender $87,9 \%$ responden mengalami nyeri sedang dan setelah diberikan aromaterapi lavender mengalami penurunan nyeri sampai pada tingkat ringan sebanyak $78,8 \%$ responden. Terjadinya penurunan skala nyeri setelah diberikan aromaterapi lavender karena wangi yang dihasilkan aromaterapi lavender akan menstimulasi talamus untuk mengeluarkan enkefalin, berfungsi sebagai penghilang rasa sakit alami. Enkefalin merupakan neuromodulator yang berfungsi untuk menghambat nyeri fisiologi.Wangi aroma lavandula (lavender) akan diteruskan oleh nervus olfaktorius menuju bagian otak kecil, yaitu nukleus raphe yang kemudian akan melepaskan neurokimia serotonin. Serotonin bekerja sebagai neuromodulator untuk menghambat informasi nosiseptif dalam medula spinalis.

Neuromodulator ini menutup mekanisme pertahanan dengan cara menghambat pelepasan substansi $\mathrm{P}$ di dalam kornu dorsalis. Pelepasan neurotransmiter substansi $\mathrm{P}$ menyebabkan transmisi sinaps dari saraf perifer (sensori) ke saraf traktus spinotalamikus. Hal ini memungkinkan impuls nyeri ditransmisikan lebih jauh ke dalam sistem saraf pusat. Penghambatan serabut saraf yang mentransmisikan nyeri (nosiseptif) akan membuat impuls nyeri tidak dapat melalui sel transmisi (sel T), sehingga tidak dapat diteruskan pada proses yang lebih tinggi di kortek somatosensoris, transisional, dan sebagainya (Tarsikah, 2012)

Hasil penelitian juga menunjukkan dari 42 populasi yang ada hanya 33 responden yang dapat dijadikan sampel karena terdapat 4 ibu bersalin yang mengalami gangguan kehamilan yaitu tekanan darah tinggi, 3 ibu bersalin dengan riwayat persalinan sectio caesarea, dan 2 ibu bersalin yang mengalami nyeri hebat sejak pembukaan pertama dengan skala nyeri 9 karena ibu merasa takut menghadapi persalinannya yang ditunjukkan dengan ciri-ciri ibu sudah dapat mentolerir rasa nyeri dan meminta 
untuk dilakukan persalinan dengan cara sectio caesarea.

Terjadinya nyeri yang hebat pada 2 ibu bersalin yang disebabkan karena rasa takut menghadapi persalinan sesuai dengan teori dari Yuliatun (2008) yang menyatakan bahwa cemas dan takut menyebabkan peningkatan ketegangan otot dan gangguan aliran darah menuju otak dan otot. Hal tersebut menyebabkan tegangan pada otot pelvis, kontraksi uterus yang terganggu dan hilangnya tenaga pendorong ibu selama kala II persalinan. Ketegangan yang lama akan menyebabkan kelelahan pada ibu dan meningkatkan persepsi nyeri serta menurunkan kemampuan ibu untuk mengontrol rasa nyerinya

Hasil penelitian juga menunjukkan meskipun sudah diberikan aromaterapi lavender masih terdapat 1 responden yang tetap mengalami nyeri persalinan dan tidak mengalami penurunan nyeri. Hal ini dapat disebabkan karena umur responden baru 19 tahun dan responden merasa tidak nyaman dengan ketidakhadiran suami pada saat proses persalinannya dan menurut Jusri Adam dan J.M.L Umboh dalam penelitian yang berjudul Hubungan antara Umur, Paritas dan Pendampingan Suami dengan Intensitas Nyeri Persalinan Kala I Fase Aktif Deselerasi di Ruang Bersalin RSUD Prof. Dr. H. Aloei Saboe Kota Gorontalo menunjukkan terdapat hubungan yang bermakna antara usia, parietas dan pendampingan suami dengan intensitas nyeri persalinan kala I fase aktif deselerasi

\section{SIMPULAN}

Ibu bersalin sebelum mendapatkan perlakuan dengan aromaterapi lavender sebagian besar mengalami nyeri sedang sebanyak 29 responden (87,9\%). lbu bersalin setelah mendapatkan perlakuan dengan aromaterapi lavender sebagian besar mengalami penurunan nyeri menjadi nyeri ringan sebanyak 26 responden $(78,8 \%)$

Ada pengaruh pemberian aromaterapi lavender terhadap pengendalian nyeri persalinan kala I pada ibu bersalin dengan $p$ value 0,001 . Terjadinya penurunan skala nyeri setelah diberikan aromaterapi lavender karena wangi yang dihasilkan aromaterapi lavender akan menstimulasi talamus untuk mengeluarkan enkefalin, berfungsi sebagai penghilang rasa sakit alami.

\section{SARAN}

Bagi pelayanan kesehatan khususnya pelayanan untuk ibu bersalin agar dapat memberikan pelayanan yang tidak hanya berorientasi pada masalah fisik, tetapi juga dapat mengatasi masalah psikologi lebih mengoptimalkan peran dari seorang tenaga kesehatan khususnya bidan dalam melakukan intervensi, tidak hanya tindakan kolaboratif saja.

Penelitian lebih lanjut dengan desain eksperimental murni diperlukan untuk mengetahui pengaruh aromaterapi lavender pada nyeri persalinan selama kala I fase aktif dan karakteristik ibu yang berhubungan dengan nyeri persalinan.

Pada penelitian ini penilaian nyeri dilakukan oleh subjek penelitian dengan NRS masih memungkinkan terjadinya bias karena nyeri bersifat sangat subjektif, sehingga perlu diupayakan penilaian nyeri menggunakan instrumen penilaian nyeri yang dilakukan oleh responden maupun peneliti.

\section{DAFTAR PUSTAKA}

Batbual. 2010. Hypnosis Hypnobirthing Nyeri

Persalinan dan Berbagai Metode 
Penanganannya. Yogyakarta : Gosyen Publishing.

Dasna. 2013. Efektivitas Terapi Aroma Bunga Lavender (Lavandula Angustifolia) terhadap Penurunan Skala Nyeri pada Klien Infark Miokard. http://jom.unri.ac.id/index.php/JOMPSIK/a rticle/view/8338. (10 Januari 2016)

Gondo. 2011. Pendekatan Non Farmakologis untuk Mengurangi Nyeri Persalinan. CDK 185/Vol.38 no.4/MeiJuni 2011. http://www.kalbemed.com/Portals/6/25 1 850pinipendekatanfarmakologis.pdf. (10 Januari 2016).

Judha Dkk. 2012. Teori Pengukuran Nyeri dan Nyeri Persalinan. Yogyakarta : Nuha Medika.

Jusri Adam \& J.M.L Umboh. 2015. Hubungan antara Umur, Paritas, dan Pendampingan Suami dengan Intensitas Nyeri Persalinan Kala I Fase Aktif Deselerasi di Ruang Bersalin RSUD Prof. Dr. H. Aloei Saboe Gorontalo Hospital. JIKMU, Vol. 5, No.2a April 2015

Maryunani. 2010. Nyeri dalam Persalinan Teknik dan Cara Penanganannya. Jakarta : Trans Info Media.

Oxorn dan Forte. 2010. Ilmu Kebidanan Patologi dan Fisiologi Persalinan. Yogyakarta : Andi Offset.

Tarsikah. 2012. Penurunan Nyeri Persalinan Primigravida Kala I Fase Aktif Pascapenghirupan Aromaterapi
Lavender. MKB, Volume 44 No. 1, Tahun 2012

Watt, Gillian and Janca, Aleksandar. 2008. Aromatherapy in Nursing and Mental Health Care. Journal of Contemporary Nurse, 30(1):69-75.

Yuliatun, Laily. 2008. Penanganan Nyeri Persalinan dengan Metode Nonfarmakologis. Malang: Bayumedia Publishing 